\title{
MORPHOMETRIC VARIATION IN THE SPECIES OF TWO SUBFAMILIES OF LYCAENID BUTTERFLIES (LEPIDOPTERA: LYCAENIDAE) OF BANGLADESH
}

\author{
Akand, S., M. A. Bashar, S. Rahman and H. R. Khan \\ Environmental Biology and Biodiversity Laboratory (EBBL), Department of Zoology, University of \\ Dhaka, Dhaka-1000, Bangladesh
}

\begin{abstract}
A laboratory examination was done on the morphometric variation of lycaenid butterflies. Identifying characteristics, viz. forewing length (FWL), hind wing length (HWL), body length (BdL) and antennal length (AntL) were used for the analysis. A total of 514 individuals of lycaenid butterflies was identified under two subfamilies Polyommatinae and Theclinae. Among them 265 individuals were placed under 19 species of Polyommatinae and 249 individuals under 25 species of Theclinae. ANOVA tests were conducted to find differences between the butterfly species of the two subfamilies through identifying characters like FWL $(\mathrm{F}=10.37, \mathrm{P}=0.005)$, HWL $(\mathrm{F}=3.81, \mathrm{P}=0.067), \mathrm{BdL}(\mathrm{F}=5.78, \mathrm{P}=0.027)$ and $\mathrm{AntL}(\mathrm{F}=2.77, \mathrm{P}=0.114)$. A linear regression analysis of FWL, HWL, BdL and AntL of the species under the two subfamilies showed significant differences between Polyommatinae and Theclinae. These differences stand among the species of both the subfamilies and produced good results to identify the species more correctly.
\end{abstract}

Key words: Lycaenidae, butterfly, species, morphometric variation, Polyommatinae, Theclinae.

\section{INTRODUCTION}

Morphometrics is the study of any quantitative measurement and analysis of morphological traits affecting on it (Digo et al. 2015). Lycaenidae is commonly known as 'Gossamer-winged butterflies' comprising a huge number of species- an estimated 6,000 species worldwide, with greatest diversity in the tropics (Ackery and Vane-Wright 1984, Fiedler 1996). They are remarkably uniform considering the number of species and genera (Ehrlich and Raven 1964). All of them are rather small in size, brilliantly coloured, and frequently showing marked sexual dimorphism (Roberts 2001).

The lycaenids under the subfamily Polyommatinae are found in all major bio-geographical areas of the world, with the highest diversity of species reported from North America, Europe and Asia (Eliot 1973). This is a large subfamily. The butterflies of this subfamily are commonly known as "Blues". Theclinae is the largest diversified subfamily of family Lycaenidae and well-represented in all regions particularly in the tropics. Butterflies of this subfamily are commonly known as "Hairstreaks".

The wing shape morphology of insects is extensively studied to clarify the relationship between closely related taxa and helps in identifying population within and between species of insects (Baylac et al. 2003, De la Riva et al. 2001, Villegas et al. 2002, Aytekin et al. 2007, Tuzun 2009). Wing measure, either wing length or wing span, is the most commonly used measure of body size in Lepidoptera (Miller 1977, 1991). Morphological shape is the most evidential aspect of an organism's phenotype. It provides a strong linkage between species genotype and its environment (Ricklefs and Miles 1994). 'Environmental-cause variations' among individuals of the same species differ and depend on the individual's ability to defense the problems in the environment (Digo et al. 2015). Changes and fluctuations in the environment represent selective pressures upon the population because both the environment and the amount of energy fixation in any given ecosystem are limited (Bashar 2016). Most of the morphological variations in moth and butterflies are due to the effects associated with the environment, whether phenotypic responses or particularly those which act during ontogenetic development (Mutanen et al. 2007). The overall pattern or venation is often a diagnostic feature of butterflies (Fres 1989). 
An attempt was made in the present study to examine the taxo-morphological characters of lycaenid butterflies of Bangladesh.

\section{MATERIAL AND METHODS}

Butterflies are seen almost in all areas of Bangladesh either cultivated or non-cultivated (forest areas) areas because they need such an ecological condition where their required plants are available (Bashar 2015). Lycaenid butterflies were collected from different forest areas of Bangladesh, namely Karerhat, Sitakundo, Mirsarai, Chunati, Fashiakhali, Eidgaon, Tonkabati, Padua of Chittagong division, Anarashbari, Satchari, Chautali, Nurjahan, Laowachara, Phoolbari, Rema-Kalenga of Sylhet division, Madhupur and Bhawal Sal forests of Dhaka division from the years 1999 to 2009. In addition some butterflies were collected from Gojni in Sherpur district, Bangladesh Agriculture University Campus in Mymensingh and Dhaka University area.

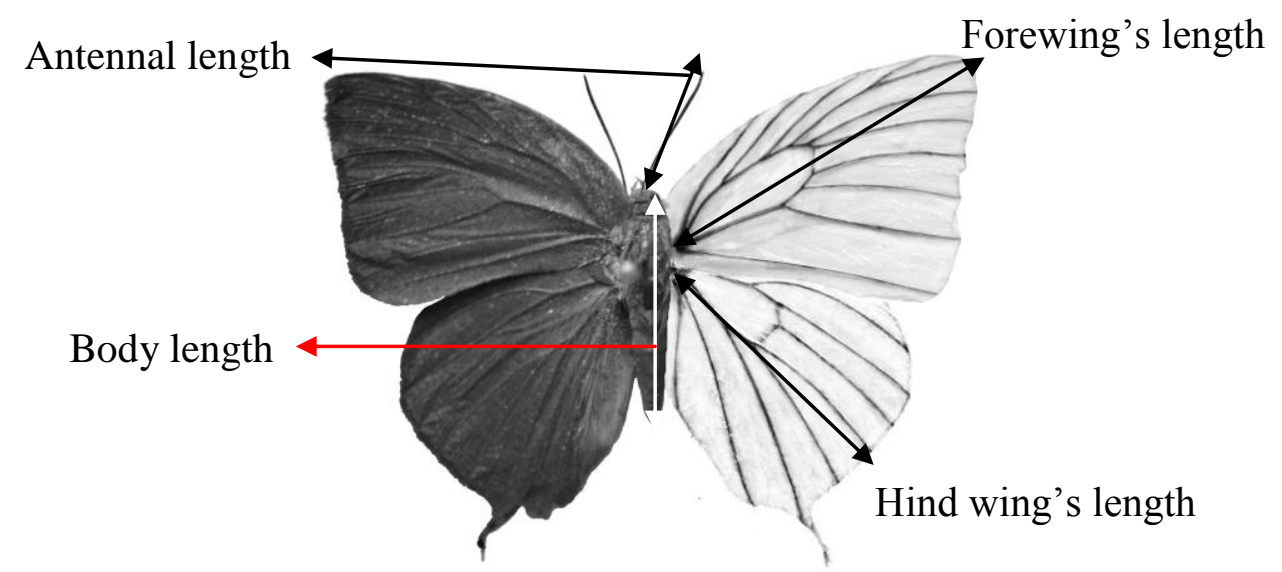

Fig. 1. Morphometric measurement of the identifying characteristics of a typical lycaenid butterfly.

Taxonomic study and identification of dry preserved lycaenid butterflies were made in the Environmental Biology and Biodiversity Laboratory (EBBL), Department of Zoology, University of Dhaka. Identification up to the species level under two subfamilies, namely Polyommatinae and Theclinae of the family Lycaenidae, was followed according to De Nicevelle (1890), Bethune-Baker (1903), Bingham (1907), Evans (1957), Eliot (1973), Pinratana (1981), Hirowatari (1992) and EkAmnuay (2006).

A clear transparent measuring scale was used for measuring the identifying variables (Fig. 1). Body length (BdL) was measured from head to tip of abdomen. Forewing's length (FWL) was measured from base to apex of the fore wing. Hind wing length (HWL) was measured from the base to the middle of termen of hind wing. Distance from base to tip of antenna is estimated as antennal length (AntL). Relationships of all the identifying characteristics (viz. forewing length, hind wing length, body length and antennal length) examined in the experimental specimens were performed by using Pearson correlation and ANOVA test. All statistical analyses were performed using SPSS software (version 16), ORIGIN software (version 8) and Microsoft Office Excel 2007.

\section{RESULTS AND DISCUSSION}

Most of the species of Polyommatinae were purple and iridescent blue with a mixture of violet, bronze and brown in colour depending on whether they are male or females. Kehimkar (2008) reported that the upper sides of males are violet, whereas in females the upper sides are blue or purple or dull bronze or brown in colour. They also have a complex pattern of dark spots and bands on the ventral side. 
They have rounded wings which are either tailed or tail-less. The antennae of these butterflies are club shaped and more or less flattened. Most of them are weak fliers, regularly seen on flowers or hovering around the food plants. Their flight is often low, erratic and up and down, and may be difficult to follow (Wauer 2002). Though some occur in dense forests, most of them are seen in open grassy areas and drier deciduous forest (Kehimkar 2008).

Table 1. Morphometric measurements (in $\mathrm{cm}$ ) of identified species under the two subfamilies of the family Lycaenidae collected from different places of the country from the years 1999 to 2009.

\begin{tabular}{|c|c|c|c|c|c|c|c|c|c|c|}
\hline \multirow{2}{*}{$\begin{array}{c}\text { Sub } \\
\text { family }\end{array}$} & \multirow[t]{2}{*}{ Species } & \multirow[t]{2}{*}{$\mathbf{N}$} & \multicolumn{2}{|c|}{ Forewing length } & \multicolumn{2}{|c|}{ Hind wing length } & \multicolumn{2}{|c|}{ Body length } & \multicolumn{2}{|c|}{ Antennal length } \\
\hline & & & Mean & Range & Mean & Range & Mean & Range & Mean & Range \\
\hline \multirow{19}{*}{ 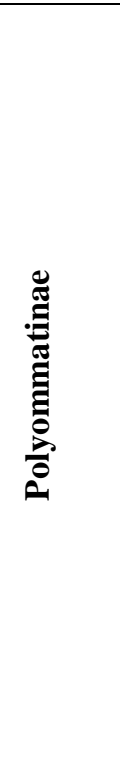 } & Psedozizeeria maha & 29 & 12 & $10-12$ & 9.58 & $8-10$ & 8.08 & $6-10$ & 5.06 & $4-6$ \\
\hline & Zizina otis & 28 & 9.92 & $8-10$ & 7.92 & $6-8$ & 7.89 & $6-8$ & 4.76 & $4-6$ \\
\hline & Neopithecops zalmora & 5 & 10.4 & $10-12$ & 8.8 & $8-10$ & 8.4 & $8-10$ & 6 & $5-7$ \\
\hline & Megisba malaya & 2 & 13 & $12-14$ & 9 & $8-10$ & 8 & - & 8 & $7-9$ \\
\hline & Chilades lajus & 8 & 13.75 & $12-14$ & 10.5 & $10-12$ & 8.33 & $8-10$ & 6 & $6-7$ \\
\hline & C. pandava & 3 & 13.33 & $12-14$ & 11.33 & $10-12$ & 9.33 & $8-10$ & 6.66 & $6-7$ \\
\hline & Nacaduba pavana & 2 & 15 & $14-16$ & 11 & $10-12$ & 11 & $10-12$ & 8 & $7-8$ \\
\hline & N. kurava & 5 & 15 & $14-16$ & 11 & $10-12$ & 11.33 & $10-12$ & 8 & $7-8$ \\
\hline & Catochrysops strabo & 6 & 15.66 & $14-16$ & 11.66 & $10-12$ & 10.66 & $10-12$ & 7 & $7-8$ \\
\hline & Tarucus callinara & 2 & 13 & $12-14$ & 11 & $10-12$ & 9 & $8-10$ & 7 & $6-7$ \\
\hline & Castalius rosimon & 78 & 14.65 & $14-16$ & 10.62 & $10-12$ & 10.03 & $8-12$ & 7 & $6-7$ \\
\hline & Discolempa ethion & 1 & 12 & - & 8 & - & 10 & - & 6 & - \\
\hline & Caleta decidia & 2 & 14 & - & 10 & - & 10 & - & 6 & - \\
\hline & Jamides bochus & 1 & 14 & - & 10 & - & 10 & - & 7 & - \\
\hline & J. alecto & 9 & 17 & $16-18$ & 13 & $12-14$ & 12.8 & $12-14$ & 8.5 & $8-9$ \\
\hline & J. celeno & 55 & 16.4 & $14-18$ & 12.38 & $10-14$ & 10.81 & $8-12$ & 7.77 & $7-9$ \\
\hline & Lampides boeticus & 6 & 16 & - & 12 & - & 12 & - & 6 & - \\
\hline & Euchrysops cnejus & 6 & 15.33 & $14-16$ & 11.33 & $10-12$ & 11.33 & $10-12$ & 6 & $6-7$ \\
\hline & Anthene emolus & 17 & 14.62 & $14-16$ & 10.62 & $10-12$ & 11.23 & $10-12$ & 8 & $8-9$ \\
\hline \multirow{25}{*}{ 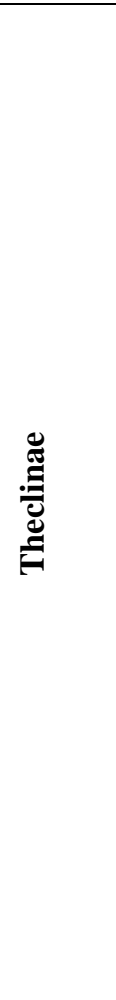 } & Arhopala amantes & 12 & 24.25 & $22-28$ & 20.25 & $18-24$ & 17 & $14-20$ & 10 & $10-12$ \\
\hline & A. pseudocentaurus & 99 & 27.60 & $24-30$ & 21.58 & $18-24$ & 17.54 & $14-20$ & 10.55 & $10-12$ \\
\hline & A. nicevillei & 2 & 24 & $22-26$ & 22 & $20-24$ & 15 & $14-16$ & 9 & $8-10$ \\
\hline & A. athada & 4 & 21.5 & $20-24$ & 17.5 & $16-20$ & 12.5 & $12-14$ & 8.5 & $8-10$ \\
\hline & A. silhetensis & 2 & 24 & $22-26$ & 22 & $20-24$ & 15 & $14-16$ & 9 & $8-10$ \\
\hline & A. agaba & 7 & 21.42 & $20-24$ & 17.42 & $16-20$ & 14.33 & $12-16$ & 8 & $8-10$ \\
\hline & A. alesia & 3 & 20.66 & $20-22$ & 16.66 & $16-18$ & 12.66 & $12-14$ & 8.66 & $8-10$ \\
\hline & A. eumolphus & 5 & 21.2 & $22-26$ & 19.6 & $20-24$ & 14.8 & $14-16$ & 9 & $8-10$ \\
\hline & Flos fulgida & 1 & 20 & - & 18 & - & 14 & - & 7 & - \\
\hline & Surendra quercetorum & 3 & 20 & $18-22$ & 18 & $16-20$ & 14.66 & $14-16$ & 8.66 & $8-10$ \\
\hline & Loxura atymnus & 38 & 18.02 & $14-20$ & 14.58 & $10-16$ & 11.73 & $8-14$ & 7 & $6-8$ \\
\hline & Ticherra acte & 1 & 16 & - & 14 & - & 12 & - & 7 & - \\
\hline & Iraota timoleon & 1 & 20 & - & 16 & - & 18 & - & 12 & - \\
\hline & Deudorix epijarbas & 10 & 16.4 & $14-18$ & 12.6 & $10-14$ & 14.28 & $12-16$ & 9 & $8-10$ \\
\hline & Rapala manea & 6 & 16 & $14-18$ & 12 & $10-14$ & 13 & $12-14$ & 9.33 & $8-10$ \\
\hline & R. pheretima & 6 & 18.66 & $18-20$ & 14.66 & $14-16$ & 12.66 & $12-14$ & 8.66 & $8-10$ \\
\hline & R. iarbus & 4 & 16.5 & $14-18$ & 12.5 & $10-14$ & 13.5 & $12-14$ & 9 & $8-10$ \\
\hline & $R$. dieneces & 2 & 15 & $14-16$ & 11 & $10-12$ & 11 & $10-12$ & 9 & $8-10$ \\
\hline & Spindasis syama & 7 & 17.14 & $14-18$ & 13.14 & $10-14$ & 12 & $10-14$ & 7.5 & $6-8$ \\
\hline & S. lohita & 1 & 18 & - & 14 & - & 14 & - & 8 & - \\
\hline & S. nipalicus & 3 & 14.66 & $14-16$ & 10.66 & $10-12$ & 11.33 & $10-12$ & 8 & - \\
\hline & Dacalana burmana & 1 & 18 & - & 16 & - & 12 & - & 8 & - \\
\hline & Remelana jangala & 5 & 19.2 & $18-20$ & 15.2 & $14-16$ & 13.2 & $10-14$ & 9.5 & $8-10$ \\
\hline & Hypolycaena erylus & 23 & 16.09 & $14-18$ & 12.38 & $12-14$ & 11.83 & $10-14$ & 8 & $7-8$ \\
\hline & Chliaria othona & 3 & 12.66 & $12-14$ & 10.66 & $10-12$ & 10.66 & $10-12$ & 7.33 & $6-8$ \\
\hline
\end{tabular}

Polyommatinae (Species no $=19$, Total individuals, $\mathrm{N}=265$ ); Theclinae (Species no $=25$, Total specimen, $\mathrm{N}=249$ ); Millimetre (mm) is used as measurement unit. 
The colour of the butterflies of Theclinae ranges from iridescent blues and greens to dull browns and grey. Males are usually bright metallic iridescent blue, green or purple on the upper side, while females are mostly brown on the upper side (Kehimkar 2008). Many of them have one or two hair-like tails on the hind wing and most of them have wavy or broken lines on the lighter coloured under surface, likely giving rise to the common name of hairstreak. Often there is a dark spot, called a "thecla spot" above the tails on the ventral surface. The butterflies in this subfamily have the antenna club in cylindrical shape. Most species have a habit of rubbing their hind wings back and forth while feeding. This special behaviour is believed to draw a predator's attention by the butterfly to its less vulnerable rear end rather than to its head (Wauer 2002). Most members of this subfamily are fast flyers and visit flowers regularly. They are fully forest dwellers and found in the forest that are more stable conditions and undisturbed.

A total number of 514 individuals belonging to two subfamilies, viz. Polyommatinae and Theclinae of lycaenid butterflies were examined morphometrically. Among them, 265 and 249 individuals belonging to 19 species of the subfamily Polyommatinae and 25 species of the subfamily Theclinae, respectively are shown in Table 1.

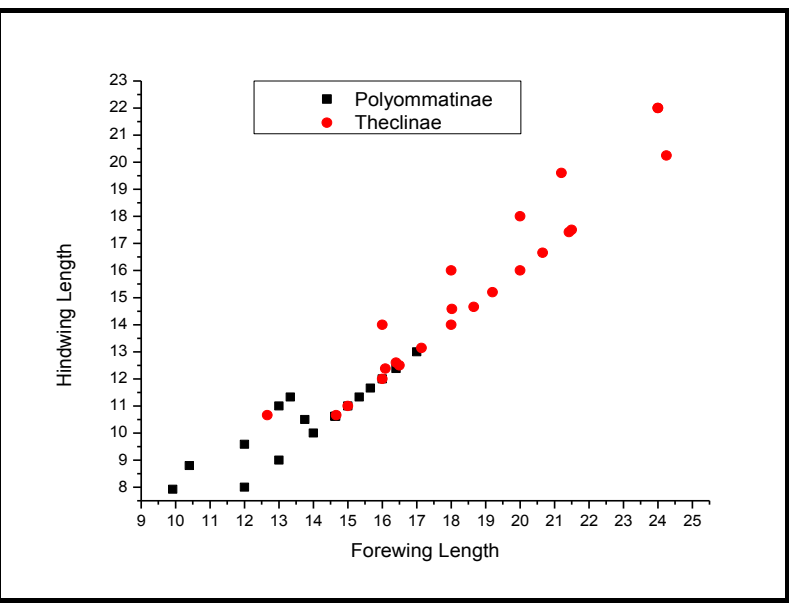

a

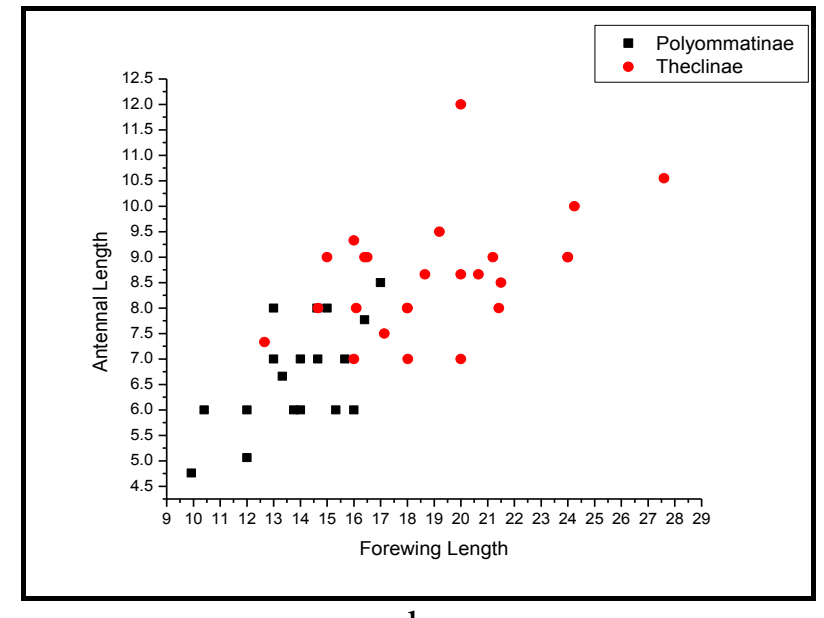

b

Fig. 2. Relations between forewing-hind wing length and forewing-antennal length among the species examined. a. Forewing-hind wing length (FWL-HWL), b. Forewing-antennal length (FWL-AntL).

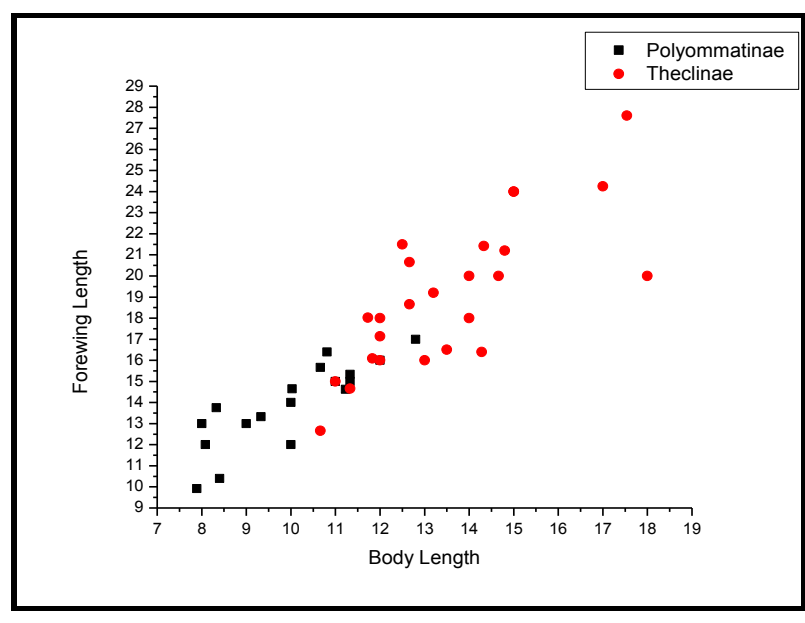

a

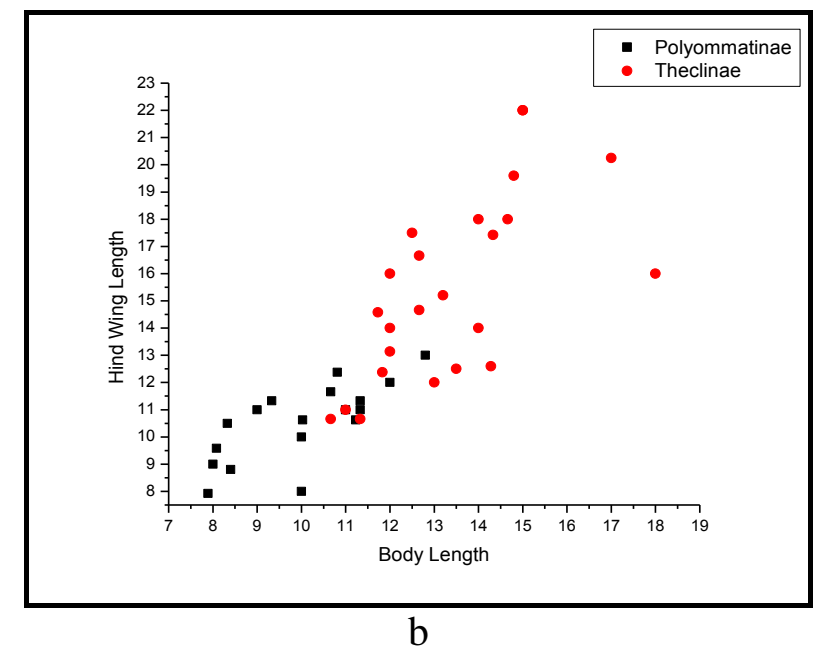

Fig. 3. Relations between body length-forewing length and body length-hind wing length among the species examined. a. Body length-forewing length (BdL-FWL), b. Body length-hind wing length (BdL-HWL). 
Morphometric analyses are found useful for species identification and classification. By this experiment, Jamides alecto was identified as the largest butterfly having $12-14 \mathrm{~mm}$ BdL and FWL ranges $16-18 \mathrm{~mm}$, whereas Zizina otis was the smallest butterfly having 6-8mm BdL and FWL ranges 8$10 \mathrm{~mm}$ under the subfamily Polyommatinae. On the other hand, Arhopala pseudocentaurus was the largest lycaenids having 14-20mm BdL and FWL ranges 24-30mm, whereas Chliaria othona having10$12 \mathrm{~mm}$ BdL and FWL range 12-14mm was the smallest under the subfamily Theclinae (Table 1).

The relationship of hind wing length and antennal length with forewing length of the species as well as the relationships of forewing length and hind wing length with body length of the species under subfamilies Polyommatinae and Thaclinae are plotted in Figs. 2 and 3, respectively. A linear positive relationship was established between the forewing length and hind wing length of the lycaenid butterflies of both subfamilies (Fig. 2a); linearity is also seen between the forewing length and antennal length (Fig. 2b). Between body length and forewing length of the lycaenids, a linear relationship developed in which the forewing length increases linearly with the body length (Fig. 3a), and hind wing length was also linearly increased with the body length (Fig. 3b).

Species of the two subfamilies differ significantly in average size. Mean values with standard deviations for each character are shown in Table 2. FWL, HWL, BdL and AntL between the species of two subfamilies are negatively correlated (Table 2). It has been assessed that differences between Polyommatinae and Theclinae with the identifying characters FWL $(\mathrm{F}=10.37, \mathrm{P}=0.005)$, HWL $(\mathrm{F}=3.81$, $\mathrm{P}=0.067)$, BdL $(\mathrm{F}=5.78, \mathrm{P}=0.027)$ and $\mathrm{AntL}(\mathrm{F}=2.77, \mathrm{P}=0.114)$ of the species are highly significant. It was found that species of Polyommatinae are morphologically smaller than that of the species of Theclinae. This study also reveals morphological variations among lycaenid butterflies of each species.

Table 2. Relationship and differences of identifying characters between subfamilies Polyommatinae and Theclinae.

\begin{tabular}{cccccccc}
\hline Characters & \multicolumn{2}{c}{ Polyommatinae } & \multicolumn{2}{c}{ Theclinae } & \multicolumn{2}{c}{ Relations } & \multicolumn{2}{c}{ Differences } \\
\cline { 2 - 8 } & Avg. & SD( \pm$)$ & Avg. & SD( \pm$)$ & $\boldsymbol{r}$ & $\boldsymbol{F}$ & $\boldsymbol{P}$ \\
\hline FWL & 13.95 & 1.91 & 19.06 & 3.50 & -0.62 & 10.37 & 0.005 \\
HWL & 10.51 & 1.39 & 15.78 & 3.60 & -0.43 & 3.81 & 0.067 \\
BL & 10.01 & 1.45 & 13.56 & 1.97 & -0.50 & 5.78 & 0.027 \\
AL & 6.77 & 1.07 & 8.66 & 1.14 & -0.37 & 2.77 & 0.114 \\
\hline
\end{tabular}

Identifying morphological traits were used to test differences between the populations of two subfamilies of lycaenid butterflies and recognize morphometric units within the species. A total number of 44 species under Polyommatinae and Theclinae subfamilies was identified having 19 species of 15 genera under Polyommatinae and 25 species of 13 genera under Theclinae. Morphological differences in identifying criteria have been considered as vital evidences for identification at species level. The results provide a taxonomic working frame. This gives us essential technique for pointing out inter and intraspecific variation in lycaenid butterflies.

\section{ACKNOWLEDGEMENTS}

The first author gratefully acknowledges the financial and administrative support from the authority of the University Grants Commission of Bangladesh, Directorate of Secondary and Higher Education, Bangladesh and Ministry of Education, Government of the People's Republic of Bangladesh to carry out this research work. The EBBL, Department of Zoology, University of Dhaka acknowledges the financial support received from the Ministry of Education, GoB to conduct a grand research programme on "Butterflies of Bangladesh". 


\section{REFERENCES}

Ackery, P. R. and R. I. Vane-Wright. 1984. Milkweed Butterflies. Their Cladistic and Biology. Department of Entomology, British Museum (Nat. Hist.). 425 pp.

Aytekin, M. A., M. Terzo, P. Rasmont and N. Çağatay. 2007. Landmark based geometric morphometric analysis of wing shape in Sibirico bombus Vogt (Hymenoptera: Apidae: Bombus Latreille). Annales de la Société Entomologique de France (n.s.). 43(1): 95-102.

Bashar, M. A. 2015. Butterflies of Bangladesh: A broad approach for nature lovers (EBBL Red-List and butterfly activities). Vol. 2. 1st ed. BCTF Publications. 177 pp.

Bashar, M. A. 2016. Vision on biodiversity: example of ecosystem services in Bangladesh. J. biodivers. conserv. bioresour. manag. 2(1): 1-6.

Baylac, M., C. Villemant and G. Simbolotti. 2003. Combing geometric morphometrics with pattern recognition for the investigation of species complex. Biol. J. Linn. Soc. 80(1): 89-98.

Bethune-Baker, G. T. 1903. A revision of the Amblypodia Group of Butterflies of the family Lycaenidae. Trans. Zool. Soc. London. 17(1): 1-171.

Bingham, L. C. T. 1907. The fauna of British India including Ceylon and Burma: Butterflies. Taylor and Francis, London, UK. 2: 282-471.

De la Riva, J., F. Le Pont, V. Ali, A. Matias, S. Mollinedo and J. P. Dujardin. 2001. Wing geometry as a tool for studying the Lutzumyia longipalpis (Diptera: Psychodidae) complex. Memorias do Instituto Oswaldo Cruz. 96: 1089-1094.

De Niceville, L. 1890. The Butterflies of India, Burmah and Ceylon. The Calcutta Central Press Co. Ltd, Calcutta, India. 3: 1-503.

Digo, E. O., K. L. M. Abad, I. J. B. Guino-o, L. K. C. Samillano, R. M. Eduque Jr., M. A. J. Torres and E. A. Requieron. 2015. Application of geometric morphometrics in the body shapes of flying fish (Parexocoetus brachypterus) in Maitum, Sarangani Province. Aquaculture, Aquarium, Conservation and Legislation, International Journal of the Bioflux Society. 8(6): 1027-1030.

Ehrlich, P. R. and P. H. Raven. 1964. Butterflies and Plants: a study in coevolution. Evolution. 18(4): 586-608.

Ek-Amnuay, P. 2006. Butterflies of Thailand: Fascinating Insects. Amarin printing and publishing public, Bangkok. 2: 523-718.

Eliot, J. N. 1973. The Higher Classification of the Lycaenidae (Lepidoptera): A Tentative Arrangement. Bull. Br. Mus. Nat. Hist. (Ent.). 28(6): 371-505.

Evans, W. H. 1957. A revision of the Arhopala group of Oriental Lycaenidae (Lepidoptera: Rhopalocera). Bull. Brit. Mus. (Nat. Hist.), London Ent. 5: 85-141.

Fiedler, K. 1996. Host-plant relationships of lycaenid butterflies: large-scale patterns, interactions with plant chemistry, and mutualism with ants. Entomologia Experimentaliset Applicata. 80(1): 259-267.

Fres, P. S. 1989. The Illustrated Encyclopaedia of the Butterfly World. Salamander Books Ltd. 275 pp.

Hirowatari, T. 1992. A Generic Classification of the Tribe Polyommatini of the Oriental and Australian Regions (Lepidoptera, Lycaenidae, Polyommatinae). Bull. Univ. Osaka Pref. Ser. B. 44: 1-102. 
Kehimkar, I. 2008. The text book of Indian butterflies. Bombay Natural History Society. Oxford University Press, Mumbai, India. 497 pp.

Miller, W. E. 1977. Wing measure as a size index in Lepidoptera: The family Olethreutidae. Ann. Entomol. Soc. Amer. 70: 253-256.

Miller, W. E. 1991. Body size in North American lepidoptera as related to geography. J. Lepido. Soc. 45(2): 158-168.

Mutanen, M., J. Itamies and L. Kaitala. 2007. Heliozelare splendella (Stainton, 1851) and $H$. Hammoniella Sorhagen, 1885: two valid species distinguishable in the genitalia of both sexes and life histories (Heliozelidae). Nota Lepidopterologica. 30(1): 79-92.

Pinratana, B. A. 1981. Butterflies in Thailand. The Viratham Press, Bangkok. Thailand. 4: 1-215.

Ricklefs, R. E. and D. B. Miles. 1994. Ecological and evolutionary inferences from morphology: an ecological perspective. In: P. C. Wainwright and S. M. Reilly (eds.). Ecological morphology. The University of Chicago Press, Chicago., pp. 13-41.

Roberts, T. J. 2001. The butterflies of Pakistan. Oxford University Press. Karachi, Pakistan. 122 pp.

Tuzun, A. 2009. Significance of wing morphometry in distinguishing some of the Hymenoptera species. African J. Biotech. 8(14): 3353-3363.

Villegas, J., M. D. Feliciangeli and J. P. Dujardin. 2002. Wing shape divergence between Rhodnius prolixusfrom Cojedes (Venezuela) and Rhodnius robustusfrom Merida (Venezuela). Infection, Genetics and Evolution. 2: 121-128.

Wauer, R. H. 2002. Butterflies of West Texas parks and preserves. Texas Tech University Press. Lubbock, Texas, USA. 78 pp. 
J. biodivers. conserv. bioresour. manag. 3(1), 2017 